\title{
Front Matter: Volume 11792
}

, "Front Matter: Volume 11792," Proc. SPIE 11792, International Forum on Medical Imaging in Asia 2021, 1179201 (20 April 2021); doi:

$10.1117 / 12.2597544$

Event: International Forum on Medical Imaging in Asia 2021, 2021, Taipei, Taiwan 


\title{
PROCEEDINGS OF SPIE
}

\section{International Forum on Medical Imaging in Asia 2021}

\author{
Ruey-Feng Chang \\ Editor
}

\section{4-26 January 2021 \\ Taipei, Taiwan}

Sponsored by

TaiHao Medical Inc. (Taiwan) • inwinSTACK Inc. (Taiwan) • EBM Technologies Inc. (Taiwan) • Wistron Medical Technology (Taiwan) • Knowtions Research Inc. (Canada) • Institute for Information Industry (Taiwan)

Technical Cosponsor

SPIE

Organized by

International Forum on Medical Imaging in Asia 2021 (IFMIA 2021) • MOST All Vista Healthcare Center (United States) • MOST Joint Research Center for AI Technology and All Vista Healthcare (Taiwan) • AINTU Smart ED (Taiwan) • NTU Center for Artificial Intelligence and Advanced Robotics (Taiwan) • NTU Graduate Institute of Biomedical Electronics and Bioinformatics (Taiwan)

Published by

SPIE

Volume 11792 
The papers in this volume were part of the technical conference cited on the cover and title page. Papers were selected and subject to review by the editors and conference program committee. Some conference presentations may not be available for publication. Additional papers and presentation recordings may be available online in the SPIE Digital Library at SPIEDigitalLibrary.org.

The papers reflect the work and thoughts of the authors and are published herein as submitted. The publisher is not responsible for the validity of the information or for any outcomes resulting from reliance thereon.

Please use the following format to cite material from these proceedings:

Author(s), "Title of Paper," in International Forum on Medical Imaging in Asia 2021, edited by Ruey-Feng Chang, Proceedings of SPIE Vol. 11792 (SPIE, Bellingham, WA, 2021) Seven-digit Article CID Number.

ISSN: 0277-786X

ISSN: 1996-756X (electronic)

ISBN: 9781510644205

ISBN: 9781510644212 (electronic)

Published by

SPIE

P.O. Box 10, Bellingham, Washington 98227-0010 USA

Telephone +1 3606763290 (Pacific Time) · Fax +1 3606471445

SPIE.org

Copyright (c) 2021, Society of Photo-Optical Instrumentation Engineers.

Copying of material in this book for internal or personal use, or for the internal or personal use of specific clients, beyond the fair use provisions granted by the U.S. Copyright Law is authorized by SPIE subject to payment of copying fees. The Transactional Reporting Service base fee for this volume is $\$ 21.00$ per article (or portion thereof), which should be paid directly to the Copyright Clearance Center (CCC), 222 Rosewood Drive, Danvers, MA 01923. Payment may also be made electronically through CCC Online at copyright.com. Other copying for republication, resale, advertising or promotion, or any form of systematic or multiple reproduction of any material in this book is prohibited except with permission in writing from the publisher. The CCC fee code is $0277-786 \mathrm{X} / 21 / \$ 21.00$.

Printed in the United States of America by Curran Associates, Inc., under license from SPIE.

Publication of record for individual papers is online in the SPIE Digital Library.

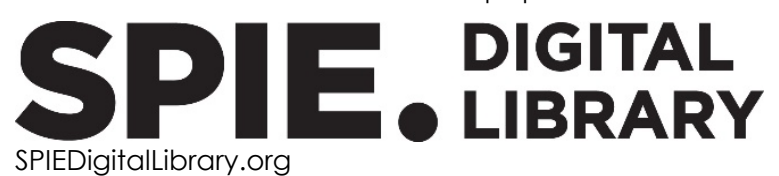

Paper Numbering: Proceedings of SPIE follow an e-First publication model. A unique citation identifier (CID) number is assigned to each article at the time of publication. Utilization of CIDs allows articles to be fully citable as soon as they are published online, and connects the same identifier to all online and print versions of the publication. SPIE uses a seven-digit CID article numbering system structured as follows:

- The first five digits correspond to the SPIE volume number.

- The last two digits indicate publication order within the volume using a Base 36 numbering system employing both numerals and letters. These two-number sets start with 00, 01, 02, 03, 04, $05,06,07,08,09,0 A, 0 B \ldots$. OZ, followed by 10-1Z, 20-2Z, etc. The CID Number appears on each page of the manuscript. 


\section{Contents}

SESSION 1 DEEP LEARNING DETECTION

1179202 Tumor detection from breast ultrasound images using mammary gland attentive U-Net [1 1792-8]

1179203 Detection of DLBCL regions in H\&E stained whole slide pathology images using Bayesian U-Net [11792-18]

\section{SESSION 2 DEEP LEARNING SEGMENTATION}

1179204 Deep 3D attention U-Net based whole liver segmentation for anatomical volume analysis in abdominal CT images [11792-5]

$1179205 \quad$ Automatic HEp-2 cell segmentation in indirect immunofluorescence images using deep learning [1 1 1792-11]

$1179206 \quad$ Lung region extraction from CT images of diffuse lung disease cases by deep learning [11792-14]

$1179207 \quad$ Relationship between number of annotations and accuracy in segmentation of the erector spinae muscle using Bayesian U-Net in torso CT images [1 1792-29]

1179208 Analysis of multiplanar integration based on uncertainty estimation in automatic segmentation of abdominal organs in 3D CT image using 2D Bayesian U-Net [1 1792-30]

1179209 Color laparoscopic image region segmentation after contrast enhancement including SRCNN by image regions [11792-35]

\section{SESSION 3 DEEP LEARNING CLASSIFICATION}

$117920 \mathrm{~A}$ Open data validation of a classification method of eye movement by a convolutional neural network [11792-10]

11792 OB Classification of lung cancer into adenocarcinoma and squamous cell carcinoma, and visualization of the grounds of classification [1 1792-15]

11792 OC Predicting 1-year mortality of acute kidney injury: a risk model using electronic health records [11792-16]

11792 OD Computer-aided analysis system for bone age in x-ray image using deep neural network [11792-17] 
11792 OE Performance improvement of Alzheimer's disease classification inspired by CNN in brain age estimation [11792-34]

11792 OF Prediction of anterior cruciate ligament injury from MRI using deep learning [11792-36]

$117920 \mathrm{G}$ Convolutional neural networks predict mitochondrial structures from label-free microscopy images [11792-39]

\section{SESSION 4 DEEP LEARNING EVALUATION}

$11792 \mathrm{OH} \quad$ Movability assessment on physiotherapy for shoulder periarthritis via fine-grained 3D ResNet deep learning [11792-2]

11792 Ol Comparison on the deep learning performance of a field of view variable color images of uterine cervix [11792-3]

$117920 \mathrm{~J} \quad$ Developing a medical artificial intelligence course for high school students [1 1792-25]

11792 OK Development of a respiratory sound labeling software for training a deep learning-based respiratory sound analysis model [11792-26]

\section{SESSION 5 DEEP LEARNING CONSTRUCTION}

11792 OL Dense 3D organ modeling from a laparoscopic video [11792-22]

$117920 \mathrm{M}$ Combining compressed sensing and deep learning using multi-channel CNN for image reconstruction in low-dose and sparse-view CT [1 1792-23]

$117920 \mathrm{~N}$ Super-resolution reconstruction using channel splitting residual edge-guided network for wideband magnetic resonance imaging [11792-28]

1179200 Probe localization from ultrasound image sequences using deep learning for volume reconstruction [11792-32]

11792 OP Image reconstruction framework for helical cone-beam CT by combining compressed sensing and deep learning [11792-33]

\section{SESSION 6 TRADITIONAL SEGMENTATION}

$117920 Q \quad$ Unpaired medical image translation between portal-venous phase and non-contrast CT volumes for multi-organ segmentation [11792-12]

11792 OR Stain transfer for automatic annotation of malignant lymphoma regions in H\&E stained whole slide histopathology images [1 1792-19] 
11792 OS Semantic feature representation and interpretation with context-free grammar and push-down automaton [11792-1]

11792 OT A feasibility study of metal artifacts reduction using weighted iterative reconstruction algorithm for frequency split metal artifact reduction [1 1792-9]

11792 OU Elevational motion estimation for 3D ultrasound with machine learning and a speckle generating gel pad [11792-21]

11792 OV Real-time volume exploration technique for holographic display [1 1792-27]

$11792 \mathrm{OW}$ An accurate bladder volume measurement algorithm via multi-dimensional image and spatial-information using point-of-care ultrasound only [11792-31]

11792 0X Online system for staging hepatic fibrosis [1 1792-38]

\section{SESSION 8 TRADITIONAL CONSTRUCTION}

11792 OY Synthetic Q-space learning with mixture distribution noise for robust DKI parameter inference [11792-13]

$117920 Z$ An iterative reconstruction method for CT metal artifact reduction using L1 norm data fidelity and nonlocal TV regularization [1 1792-20] 
Proc. of SPIE Vol. 11792 1179201-6 Downloaded From: https://www.spiedigitallibrary.org/conference-proceedings-of-spie on 26 Apr 2023
Terms of Use: https://www.spiedigitallibrary.org/terms-of-use 